\title{
Az „Open Access-előnyöK” megnyilvánulása A HAZAI TUDÁSPRODUKCIÓBAN: BIBLIOMETRIAI HATÁSVIZSGÁLAT ${ }^{1}$
}

Soós SÁndor, Kiss AnNA

\section{Bevezetés}

Az „Open Access-előnyök” körét mára széleskörű tudományos, gazdasági és társadalmi hatások listájaként szokás nyilvántartani. Ezek közé tartozik a tudományos (publikációs - láthatósági, idézettségi előnyökben megnyilvánuló, illetve pályázati) versenyképesség, a nemzetköziesedés, az ipar - akadémia tudásáramlás akadálytalansága és ezen keresztül a tudásmenedzsment- és innovációs folyamatok felgyorsítása, a kutatás társadalmi átláthatóságának és a kutatásértékelés lehetőségeinek jelentős kibővítése.

Az egyik legelterjedtebb feltételezés, hogy az OA-publikációk - főként nagyobb láthatóságuk, elérhetőségük miatt - magasabb idézettséget érnek el, mint a velük összemérhető, azonos szakterületi, jellegbeli, szerzőségi stb. csoportba sorolható nem-OA közlemények. A hipotézis vitatott (lásd a Kapcsolódó kutatások című szakaszt), ugyanakkor az evidenciák többsége általánosságban alátámasztja az ún. OA-idézettségi előnyt.

Az alábbiakban bemutatott kutatás az OA-idézettségi előny posztulátumából indul ki, célja pedig annak empirikus, „tényalapú” felmérése, hogy a nyílt hozzáférésű közlésnek a hazai tudományos kibocsátás vonatkozásában is tulajdonítható-e efféle előny, illetve, ha igen, ez az előny ténylegesen az OA-státusznak köszönhető-e. Ennek megfelelően a vizsgálat két kutatási kérdésre irányul:

1 A kutatást a Nemzeti Kutatási, Fejlesztési és Innovációs Hivatal

OTKA K 116163 számú pályázata támogatta. 
RQ1. Létezik, illetve kimutatható-e a hazai intézményekhez köthető Open Access közlemények körében idézettségi előny/fölény a nem nyílt hozzáférésű publikálással szemben?

RQ2. Mekkora hatással rendelkezik, mennyiben nyújt magyarázatot az OA-státusz az idézettség viselkedésére (feltételezett növelésére) vonatkozóan, ha elkülönítjük a többi, idézettséget befolyásoló tényező hatásától? E kérdés kapcsán milyen összefüggések mutathatók ki az OA-státusz és a további közleményjellemzők idézettségre gyakorolt hatása között?

A fenti kutatási kérdések mindegyike hazai viszonylatban merül fel. A kérdések ugyanakkor az alábbi szakaszban összefoglalt nemzetközi eredményekre reflektálnak.

\section{KaPCSOLÓDÓ KUTATÁSOK}

Lawrence (2001) volt az első, aki az OA-publikálásban rejlő lehetőségeket az idézettség növelésére megfogalmazta empirikus tanulmányban. 2001 óta számos tanulmány született, amelyek alátámasztják, avagy cáfolják az Open Access-publikáláshoz kapcsolódó potenciális idézettségi előny létezését. Az idézettségi előny hasznosságáról és következetességéről a különböző kutatási területeken turbulens vita zajlik, mert az idézettségi előny nagysága az egyes tudományágakban jelentősen eltérő. Az eddigi tanulmányok által azonosított általános tendencia azonban azt jelzi, hogy a legtöbb tudományágban legalább kismértékű összefüggés mutatkozik az OA-publikálás és a megnövekedett idézettségi között (1. táblázat). 
1. táblázat: Főbb tudományos publikációk, amelyek az OA-publikáláshoz kapcsolódó idézettségi előnyt vizsgálták és számszerüsítették.

\begin{tabular}{|c|c|c|}
\hline Szerző & Tudományterület & Hivatkozási előny \\
\hline Eysenbach (2006) & Természettudomány & $+210-+290 \%$ \\
\hline $\begin{array}{l}\text { Atchison and Bull } \\
(2015)\end{array}$ & Politikatudomány & $\begin{array}{l}\text { Statisztikailag } \\
\text { szignifikáns előny }\end{array}$ \\
\hline $\begin{array}{l}\text { Kousha and Abdoli } \\
(2010)\end{array}$ & Agrártudomány & $+621 \%$ \\
\hline Davis (2011) & $\begin{array}{l}\text { Társadalom és } \\
\text { Bölcsészettudományok }\end{array}$ & $\begin{array}{l}+1 \% \text {, de statisztikai- } \\
\text { lag nem megkülön- } \\
\text { böztethető }\end{array}$ \\
\hline Sahu et al. (2015) & Egészségtudományok & $+300 \%-+450 \%$ \\
\hline $\begin{array}{l}\text { Wohlrabe and } \\
\text { Birkmeier (2014) }\end{array}$ & Gazdaságtudomány & $\begin{array}{l}+35 \%-+64 \% \\
\text { a használt adatbázis } \\
\text { függvényében }\end{array}$ \\
\hline Zhang (2006) & Kommunikációtudomány & $200 \%$ \\
\hline Lawrence (2001) & Számítástudományok & $+157 \%-+284 \%$ \\
\hline \multirow[t]{2}{*}{ Xu et al. (2011) } & $\begin{array}{l}\text { Bölcsészettudományok, } \\
\text { Elettudományok, Matematika és } \\
\text { Fizika, Egészségtudományok, }\end{array}$ & $-49.24 \%-+87.73 \%$ \\
\hline & Társadalomtudományok & \\
\hline Hajjem et al. (2006) & $\begin{array}{l}\text { Biológia, Pszichológia és } \\
\text { Neveléstudomány, Szociológia, } \\
\text { Egészségtudomány, } \\
\text { Politikatudomány, } \\
\text { Gazdaságtudomany, } \\
\text { Jogtudomány, Gazdálkodás és } \\
\text { menedzsment, }\end{array}$ & $+36 \%-172 \%$ \\
\hline $\begin{array}{l}\text { McCabe and Snyder } \\
(2014)\end{array}$ & $\begin{array}{l}\text { Ökológia, Botanika, } \\
\text { Multidiszciplináris tudományok } \\
\text { és Biológia }\end{array}$ & $+8 \%$ \\
\hline $\begin{array}{l}\text { Evans and Reimer } \\
(2009)\end{array}$ & Mindegyik & $\begin{array}{l}\text { +8\% az új } \\
\text { publikációkra; } \\
\text { +16\% a fejlődő } \\
\text { országokban } \\
\text { készült publikációk }\end{array}$ \\
\hline Wang et al. (2015) & Mindegyik & $+111 \%-+152 \%$ \\
\hline
\end{tabular}


Bizonyítékok támasztják alá az OA-publikáláshoz kapcsolódó idézettségi előnyt, ennek az előnynek a nagysága továbbra is jelentősen változó. Az OA-publikáláshoz kapcsolódó idézettségi előnyre vonatkozó becslések +8\% (biológia) és $+600 \%$ (agrártudomány) között mozognak (Swan 2010; Wagner 2010). A megfigyelt hivatkozási előnyök jelentős heterogenitása a különböző tudományterületeken található publikációs és idézési hagyományokból és kultúrákból adódhat, valamint az OA típusa, és az alkalmazott bibliometriai indikátor is szerepet játszhat az idézettségi előny eltérő mértékében. A Green OA például közösségi standardnek számít olyan területeken, mint a nagy energiájú fizika vagy a matematika, de még nem terjedt el széles körben az élettudományok területén. Az ilyen „pre-print” publikációk az idézetek átlagos számának, az összes idézetek számának és az idézetek akkumulációs sebességének általános növekedésével is összefüggésben állnak (Aman 2014; Gentil-Beccot et al. 2010). Más tanulmányok csak akkor tudtak alátámasztani a nagy idézettségi előnyöket (+600\%), ha a releváns előrejelzéseket kihagyták (McCabe \& Snyder 2014), ami potenciális torzító hatást jelez. Ha az idézettségi előny kicsi vagy egyáltalán nem létezik, ez arra utalhat, hogy ezeken a kutatási területeken megfelelő hozzáférés áll rendelkezésre a szakirodalomhoz, így az OA nem biztosít lokális hozzáférési előnyt, vagy az OA elfogadása még nem érte el azt a szintet, amikor minden ilyen előny statisztikailag kimutathatóvá vált.

Eysenbach (2006) egy longitudinális tanulmányban összehasonlította a Proceedings of the National Academy of Sciences multidiszciplináris folyóiratban megjelent publikációk egy kohortjának idézettségi hatását, amely mind az OA, mind a nem OA közzétételi lehetőségeket kínál. Az eredmények azt mutatták, hogy a nem OA-publikációk kétszer nagyobb valószínűséggel maradnak idézetlenek hat hónappal a megjelenés után, mint az OA-publikációk. Ezenkívülaz OA-publikációk átlagos idézettségi száma több mint kétszeresére nőtt, összehasonlítva a nem OA-publikációkkal. A tanulmány megkülönböztette az OApublikációk típusát is, nevezetesen a Green OA és a Gold OA-t. 
A Gold OA-nek nagyobb volt az általános tudományos hatása, mint a Green OA publikációknak.

A pszichológia területén megjelent publikációk tanulmányozása során Anderson (2013) megállapította, hogy a szövegben közölt finanszírozási forrásokat megjelenítő publikációkat gyakrabban idézték, és ezen publikációk kapcsolódtak más, magasan idézett publikációkhoz, összehasonlítva a finanszírozási forrásokat fel nem tüntető publikációkkal. Zhao (2010) könyvtár- és információtudományi területen végzett hasonló tanulmányában a támogatott kiadványok nagyobb idézettséggel bírtak, mint a támogatást nem kapó kiadványok. Bár ezek a tanulmányok azt mutatják, hogy a kutatások finanszírozása összefüggésben van a megnövekedett hivatkozási arányokkal, a publikációk hozzáférhetőségét egyik tanulmány sem vette figyelembe.

Craig és munkatársai 2007-ben készült kritikai elemzése során három nem kizárólagos posztulátumot vizsgált, amikor az OA és a nem OApublikációk közötti idézettségi különbségeket vizsgálta: az idézettségi előny 1) a publikáció OA státuszának köszönhető, 2) szelekciós torzítás (azaz a szerzők kiválasztják legjobb munkáikat, amelyeket nyilvánossá tesznek), és 3) korai megtekintési effektusok (azaz a publikáció rendelkezésre állásának hosszabbítása). Rámutattak olyan tanulmányokra, amelyek során az egyik posztulátum vizsgálatának eredménye (pl. a korai nézet) feltárta, hogy az idézések száma megmagyarázható egy másik posztulátummal (pl. szelekciós torzítás), és azt javasolták, hogy a későbbi tanulmányokban szigorúbb módszerekre van szükség az ok-okozati összefüggések vizsgálatához (Craig et al. 2007).

Az OA-publikációk és az idézettségi előny közötti lehetséges okozati viszonyok elhatárolásához és annak meghatározásához, hogy milyen feltételek mellett láthatjuk, hogy az OA hatással van-e az idézettségi mutatókra, jövőbeni kutatásokra lesz szükség. Ezt randomizált, kontrollált vizsgálatok útján lehet elvégezni minden tudományterületre kiterjedően, így szélesebb körű bizonyítékot szolgáltatnának a 
tudományterületekre specifikus OACA előfordulására. Sok releváns primer és néhány szekunder kutatás született már ebben a témában; ezek a tanulmányok értékes kontextust és áttekintést nyújtanak, azonban nem voltak átfogók, és az alkalmazott módszerek leírása nem biztosította a reprodukálhatóságot. Az OA-publikálás hatása az idézettségre továbbra sem egyértelmű, különösen a tudományágak, az adatforrások, a publikációs modellek és egyéb kontextusbeli tényezők figyelembevételével.

Langham-Putrow és munkatársai 2021-ben szisztematikus irodalmi áttekintést készítettek, amelyben 134 kutatást vizsgáltak az OA módjának, a publikációk típusainak és a vizsgált tudományágak eltéréseit az OACA-val összefüggésben. Elemzésük eredményei azt mutatták, hogy a vizsgálatba bevont kutatások többsége (47,8\%) alátámasztja az OA-publikáláshoz kapcsolódó idézettségi előnyt, míg 27,6\% nem mutatott ki idézettségi előnyt. A vizsgálatok 23,9\%-a szerint nem volt egyértelmü idézettségi előny, azonban bizonyos folyóiratok, bizonyos időszakok vagy tudományterületek előnyt jelentettek. Nem volt statisztikailag szignifikáns összefüggés az OA-publikációs mód és az eredmények között. Az OA-idézettségi előnyt alátámasztó megállapítások az OA módjától függetlenek: a zöld OA-ra irányuló vizsgálatok $72 \%$-a, az arany OA -ra összpontosítók 39,6\%-a és az OA módot nem megjelölő kutatások 52,2\%-a mutatta ki az OA-publikáláshoz kapcsolódó idézettségi előnyt. Statisztikailag szignifikáns összefüggést találtak a tudományterület és az OApublikáláshoz kapcsolódó idézettségi előny között $(\mathrm{X} 2(18,134)=$ 42,763, p <0,001). A multidiszciplináris tudományterülettel foglalkozó tanulmányok pozitív kapcsolatot mutattak OA publikáláshoz kapcsolódó idézettségi előnnyel. Az OA-publikáláshoz kapcsolódó idézettségi előnyre vonatkozó megállapítások gyakoribbak voltak a társadalomtudományokban (66,7\%), az orvostudományban és az egészségtudományokban (52,8\%), valamint a természettudományokban (45,5\%). Mind az agrártudományokban, mind a tudományterületet nem meghatározó tanulmányokban a vizsgálatok 25\%-a bizonyította az OA-publikáláshoz kapcsolódó idézettségi előnyt. A vizsgálati minta 
heterogenitása miatt a metaanalízis készítése nem volt lehetséges. Különbségek mutatkoztak az alkalmazott módszerekben és mutatókban is. A jövőbeli tanulmányoknak be kell számolniuk legalább az OA módjáról, az OA és nem OA-publikációk számáról, a felhasznált adatok összehasonlíthatóságáról, az időkeretről (idézési ablak), egy közös mutatóról (pl. medián idézettség publikációnként), valamint a zavaró tényezők és azok kezelésének módjáról ahhoz, hogy megbízható és reprodukálható eredmények szülessenek.

\section{ANYAg és módszer}

A hazai tudományos kibocsátásban feltételezett OA-előny empirikus megközelítéséhez a Web of Science (WoS) adatbázisaiban nyilvántartott, legalább egyszeresen magyar intézményhez affiliált közleményeket tekintettük vizsgálati populációnak. Az adatgyüjtést az 2014-2018 közötti ötéves periódusra korlátoztuk, több megfontolás alapján: egyrészt az ötéves időszakasz sztenderd vizsgálati egységnek tekinthető az értékelő tudománymetriában, másrészt ez a legközelebbi olyan időszak, amelynek záróévétől számítottan legalább három év eltelt. Utóbbi azért fontos, mert a szakmai konszenzus értelmében a legtöbb területen minimálisan a közléstől számított három év szükséges a jellemző idézettségi ráta beállásához, amelyre megbízható és összemérhető idézettségi statisztikák alapozhatók. A végső minta $n=45440$ közleményt tartalmazott.

Az idézettségi előny és az OA-státusz kapcsolatának tesztelése céljából egyrészt a mintában szereplő közlemények mindegyikére egy olyan idézettségmutatót alkalmaztunk, amely az idézettségi hatást összemérhető módon fejezi ki heterogén, tudományterületileg, közlési év stb. tekintetében változatos mintában is. Másrészt a hazai közleménymintát három további indikátor- vagy változószettel jellemeztük. A három csoport azokat a tényezőket gyűjti össze, amelyek a szakmai konszenzus értelmében jelentős hatást gyakorolnak az idézettség alakulására (Tahamtan et al. 2016), köztük a kérdéses, OAstátuszt, illetve besorolást kódoló változókkal. Ezekre a változókra/ 
mutatókra az alábbiakban az idézettségi tényező/faktor terminussal hivatkozunk. Ez a mozzanat alapvető fontosságú elemzéseink szempontjából, hiszen egyik kutatási kérdésünk arra vonatkozik, hogy az OA-közlemények feltételezett idézettségi előnye vagy viselkedése mennyiben tulajdonítható az OA-státusznak, mennyiben pedig más közleményjellemzőknek. Ez utóbbi kérdés pedig az OA-státusz és a további idézettségi tényezők kapcsolatának feltárásával válaszolható meg, ami az idézettségre gyakorolt hatásukat illeti. Az alkalmazott hatásmutató, illetve a három változószett és azok tagjai az alábbiak.

- Idézettségi hatás. Az közlemények idézettségi hatásának mérésére az ún. Normalizált Idézettségi Rátát (Normalized Citation Score, NCS) alkalmaztuk, amely minden publikáció idézetszámát annak tudományterületén és közlési évében megjelent publikációk nemzetközi idézettségi átlagához viszonyítja. Értéke $1(>1,<1)$, ha a közlemény idézettsége megfelel a nemzetközi átlagnak (magasabb, illetve alacsonyabb annál).

- Tudományterületi besorolást kódoló változók. A tudományterületi hatás mérésére bevezetett, az Essential Science Indicators (ESI) tudományterületi felosztására épülő 22-elemű változószett. A kétértékű („dummy”) változók a közlemény valamely ESItudományterülethez való hozzátartozását fejezik ki ( 1 = a közlemény a területhez tartozik, 0 = a közlemény más területhez tartozik).

- Folyóiratrangot, nemzetköziességet és társszerzőséget kódoló változók. A legfontosabb idézettségi tényezők mutatói, ugyancsak többnyire kétértékű változókkal: (1) a közlő folyóirat szakterületi rangsorban elfoglalt helye, kvartilis-besorolása (Q12: az l-es vagy 2-es kvartilishez tartozó közlemény, Q34: a 3-as vagy 4-es kvartilishez tartozó közlemény), (2) nemzetközi társszerzőségben készült közlemény (INT, értéke 1 = nemzetközi, 2 = hazai szerzőség vagy társszerzőség), illetve (3) a szerzőszám (CoAU), utóbbi értéke megnevezésével összhangban a közlemény szerzőinek számával egyezik meg.

- OA-státuszt kódoló változók. A közlemény OA-státuszát rögzítő három dummy változó a következő (célszerű volt egyetlen háromértékű változó helyett minden OA-státuszhoz külön 
változót definiálni a részletes modellvizsgálatok kivitelezhetősége érdekében): NemOA (1 = a közlemény nem nyílt hozzáférésű), GoldOA ( $1=$ a közlemény Gold OA státusú), illetve only.green ( 1 = a közlemény Green OA státuszú, de további OA-státusza, pl. Gold, nincsen). További OA-változatokat egyelőre nem vettünk figyelembe.

A mintából létrehozott, fentiek szerint kialakított adatbázison az alábbi elemzéseket végeztük el:

(1) Leíró jellegű analízis révén összehasonlítottuk a különböző OAstátuszú közleménykörök tudományos hatását.

(2) Szintén leíró, kereszttáblás elemzések révén megvizsgáltuk az OA-státusz, illetve a további idézettségi tényezők összefüggését, interakcióit az idézettségre gyakorolt hatás tekintetében.

(3) $\mathrm{Az}$ OA-státusznak a tudományos hatás mértékére gyakorolt befolyását a többi idézettségi tényezőtől elkülönítendő, regresszióanalízis formájában az idézettség mértékét magyarázó modellt állítottunk fel. Ennek kiértékelése lehetőséget nyújtott az OA-státusz hozadékának számszerű becslésére, illetve a többi tényező szerepével való számszerű összevetésére.

$\mathrm{Az}$ egyes elemzések további módszertani részleteit az Eredmények vonatkozó részében, azokkal összefüggésben mutatjuk be.

\section{EREDMÉNYEK}

A hazai kibocsátás OA-státusz szerinti alapmegoszlásait tekintve a nyílt hozzáférésű publikációs utak egyértelműen előnyös helyzetet eredményeznek (2. táblázat). A vizsgált időszak OA-kibocsátása - az összes OA-utat figyelembe véve - hozzávetőleg azonos méretű, illetve részarányú, mint a nem nyílt hozzáférésű frakció. Ebből adódóan a két kör átlagos idézettségi mutatói jól összevethetők, amelyek pedig az OA-kör fölényét támasztják alá. Közelebbről, az OA-közlemények átlagos normalizált idézettsége (MNCS) közel kétszer akkora, mint 
a nem-OA közleményeké - illetve, mint a nemzetközi átlag. Az ún. átlagos percentilis mutatója értelmében pedig az OA-frakcióhoz tartozó közlemények jellemzően a tudományterület idézettségi rangsorának felénél, míg a nem-OA közlemények a harmadánál foglalnak helyet.

2. táblázat: A vizsgált hazai kibocsátás mennyiségi és idézettségi mutatói OA-státusz szerint

\begin{tabular}{lrr}
\hline & OA & Nem-OA \\
Közleményszám & 21663 & 23777 \\
MNCS & 1.72 & 1.01 \\
Átlagos percentilis & 50.22 & 33.41 \\
\hline
\end{tabular}

Az idézettségi tényezók és az OA-státusz hatásának kapcsolata - interakciók

A fent leírt általános kép hátterének, illetve esetleges torzításainak feltárását célozza annak vizsgálata, hogy az OA-státusz idézettségre gyakorolt hatása milyen összefüggést mutat az idézettséget befolyásoló további változókkal (idézettségi faktorokkal) a hazai mintán belül. $\mathrm{Az}$ alábbiakban a három legfontosabb idézettségi faktor, a tudományterület, a folyóiratrang, illetve a nemzetköziesség mutatóival feltárt interakciókat ismertetjük.

A hazai kibocsátás eltérő OA-státuszú csoportjainak idézettségi hatását mutatja be az l. ábra tudományterületi bontásban - vagyis a tudományterületi besorolás, illetve az OA-státusz hatásának összefüggését jeleníti meg. A kimutatás tanúsága szerint (1) az OAelőny tudományterület-függő, amennyiben a három görbe (NemOA, Green-OA, Gold-OA) korántsem párhuzamosan fut, illetve rendszeresen keresztezi is egymást: az idézettség OA-státuszok közti arányai területenként változnak. Ugyanakkor az is jól látható, hogy (2) a nyílt hozzáférésű közlemények csaknem minden területen magasabb átlagos idézettséget érnek el, mint a nem OA-közlemények, tekintve, hogy a „Nem-OA” görbe jórészt az OA-görbék alatt fut. A részleteket a 3. táblázat mutatja be: az ábrán is könnyen azonosítható egy-két terület, 
ahol az OA-státusz előnye nem mutatkozik meg, vagy egyenesen kevésbé látszik előnyösnek, a mérnöki tudományok (Engineering) és az anyagtudományok (Materials Science). Másrészt, jelentős előnyt élvez a „Gold” út a fizika és űrtudományok terén (Physics, Space Science). A „Green” út előnye többszörösen felülmúlja a másik két OA-státuszt a klinikai orvostudomány és a molekuláris biológia területén (Clinical Medicine, Molecular Biology and Genetics). Figyelemre méltó, hogy a „Green” útnak megfelelő görbe az esetek többségében a „Gold”-görbe felett halad, a leginkább ígéretes OA-státuszként feltüntetve ezt a módozatot (ezt a megfigyelést támogatja a regressziós eredményekről szóló szakasz is).

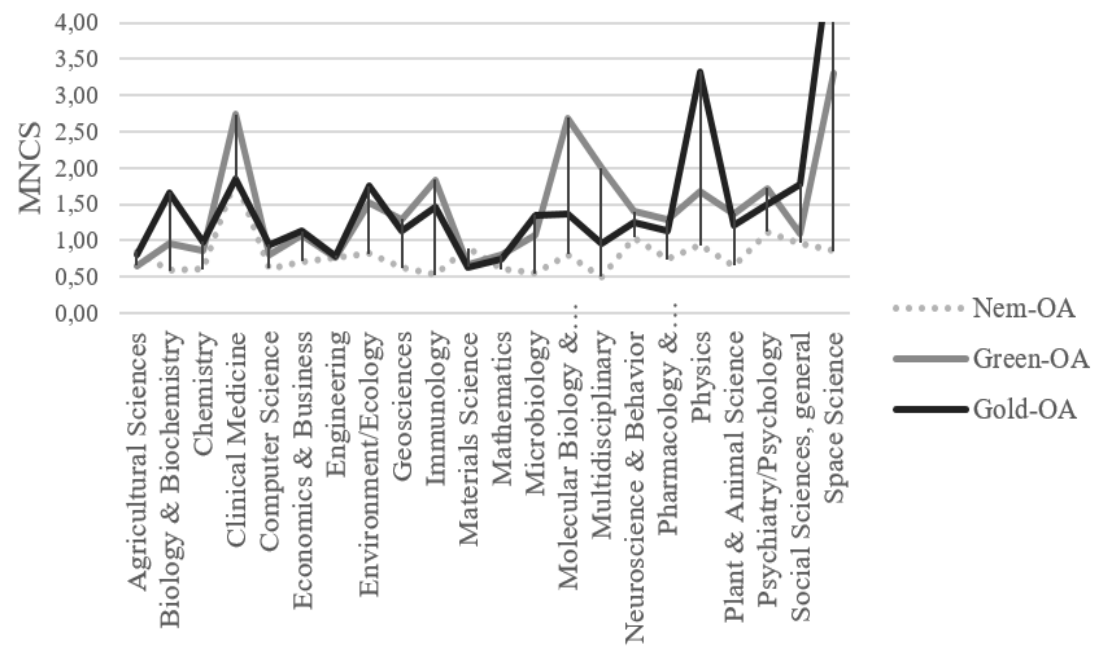

Tudományterület (ESI)

1. ábra: A tudományterületi besorolás és az OA-státusz interakciója a vizsgált hazai mintában 
3. táblázat: A vizsgált hazai kibocsátás átlagos normalizált idézettsége (MNCS) tudományterületek és OA-státusz szerint

\begin{tabular}{lrrr}
\hline Tudományterület (ESI) & Nem-OA & Green & Gold \\
Agricultural Sciences & 0.85 & 0.65 & OA \\
Biology \& Biochemistry & 0.59 & 0.97 & 1.67 \\
Chemistry & 0.61 & 0.87 & 0.98 \\
Clinical Medicine & 1.86 & 2.74 & 1.85 \\
Computer Science & 0.61 & 0.81 & 0.95 \\
Economics \& Business & 0.71 & 1.07 & 1.13 \\
Engineering & 0.77 & 0.76 & 0.79 \\
Environment/Ecology & 0.82 & 1.52 & 1.75 \\
Geosciences & 0.63 & 1.30 & 1.14 \\
Immunology & 0.53 & 1.84 & 1.47 \\
Materials Science & 0.90 & 0.68 & 0.64 \\
Mathematics & 0.60 & 0.80 & 0.74 \\
Microbiology & 0.55 & 1.07 & 1.35 \\
Molecular Biology \& Genetics & 0.81 & 2.69 & 1.37 \\
Multidisciplinary & 0.50 & 2.00 & 0.96 \\
Neuroscience \& Behavior & 1.04 & 1.40 & 1.26 \\
Pharmacology \& Toxicology & 0.75 & 1.29 & 1.14 \\
Physics & 0.94 & 1.68 & 3.33 \\
Plant \& Animal Science & 0.66 & 1.37 & 1.20 \\
Psychiatry/Psychology & 1.12 & 1.72 & 1.50 \\
Social Sciences, general & 0.96 & 1.10 & 1.78 \\
Space Science & 0.85 & 3.29 & 5.23 \\
\hline
\end{tabular}


A következő kiemelt idézettségi faktor a folyóiratrang, vagyis a közlő folyóiratok elhelyezkedése a szakterületi rangsorban (kvartilisekben, JIF alapján). A kvartilis-besorolás és az OA-státusz hatásának mintabeli interakcióját szemlélteti az 2. ábra. Az interakció jelensége itt is szembeötlő: (1) a három OA-kategóriában eltérő meredekséggel változik, növekszik az átlagos idézettségi hatás a 3-4. kvartilisbe tartozó közlemények köréből átlépünk az 1-2. kvartilisbe tartozó közlemények körébe. Továbbra is igaz viszont, hogy (2) a Nem-OA publikációk mindkét körben alacsonyabb átlagos hatást váltanak ki, mint akár a Green-, akár a Gold-OA publikációk. A tudományterületekre kapott eredményekkel az is összhangban áll, hogy a „Green” út itt is feltűnően sok hozadékkal kecsegtet: a részleteket közlő 4. táblázat számszerűen is tanúsítja, hogy míg a 3-4. kvartilisben a Green és a nem nyílt hozzáférésű közlemények átlagos hatása lényegében azonos (kb. 0.4), addig az 1-2. kvartilisben a Green-OA kör ennek öt-hatszorosát (2.2), míg a NemOA kör a háromszorosát éri el (1.33). Ezzel a Green utas közlemények még a Gold OA-kör hatását is enyhén felülmúlják.

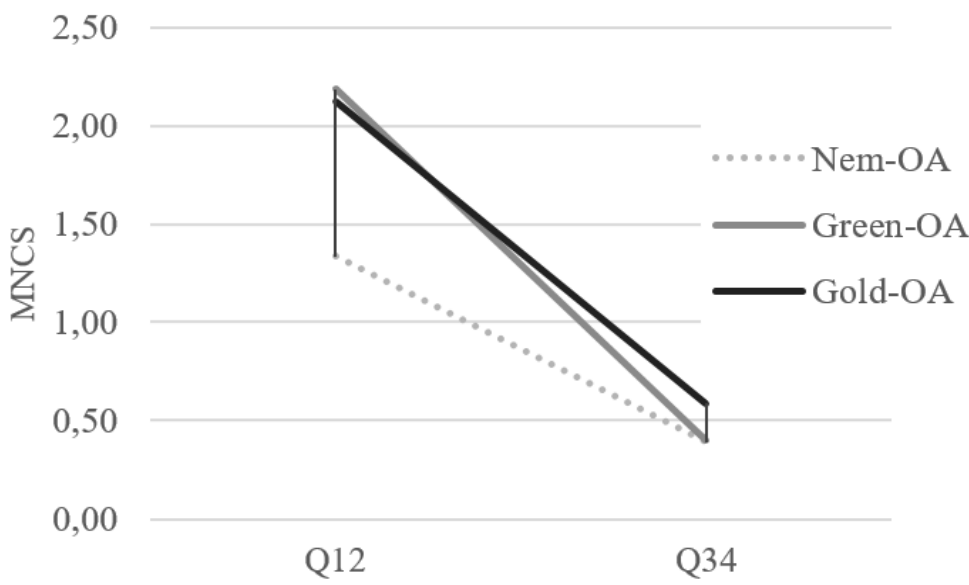

Folyóiratrang

2. ábra: A folyóiratrang és az OA-státusz interakciója a vizsgált hazai mintában 


\begin{tabular}{lrrrr} 
4. táblázat: & \multicolumn{2}{l}{$\begin{array}{l}\text { A vizsgált hazai kibocsátás átlagos normalizált } \\
\text { idézettsége (MNCS) folyóiratrang és OA-státusz } \\
\text { szerint }\end{array}$} \\
$\begin{array}{l}\text { Felső 50\% } \\
\text { Nem-Q12 }\end{array}$ & Q12 & Alsó 50\% \\
Nem-OA & 0.38 & 1.33 & 1.29 & 0.39 \\
Green-OA & 0.42 & 2.18 & 2.17 & 0.40 \\
Gold-OA & 0.67 & 2.12 & 2.09 & 0.59 \\
\hline
\end{tabular}

A harmadik tényező, amely a vonatkozó szakirodalom szerint jelentős hatást gyakorol az idézettségre, a nemzetközi társszerzőség, nemzetköziesség. Ennek a mutatónak az OA-státusszal adódott interakcióját szemlélteti az 3. ábra. A kimutatás lényegében megismétli az iménti, a folyóiratrangra vonatkozó eredményeket. (1) Az interakció látványos, az egyes OA-kategóriákban a nemzetköziesség eltérő mértékben növeli az átlagos hatást, de(2)a Nem-OAtípusú közlemények megint mindkét esetben (nemzetközi, nem nemzetközi) alacsonyabb hatást váltanak ki átlagosan. A három OA-státusz ugyanúgy látszik reagálni a nemzetköziesség tényezőjére, ahogyan a folyóiratrang mutatójára: a Green út a nemzetközies kategóriában megötszörözi a hatást (a nem-nemzetközihez képest), míg a Nem-OA út „csupán” megháromszorozza, illetve ezzel a Green-OA nemcsak az Nem-OA, hanem a Gold-OA hozadékát is felülmúlja (5. táblázat). 


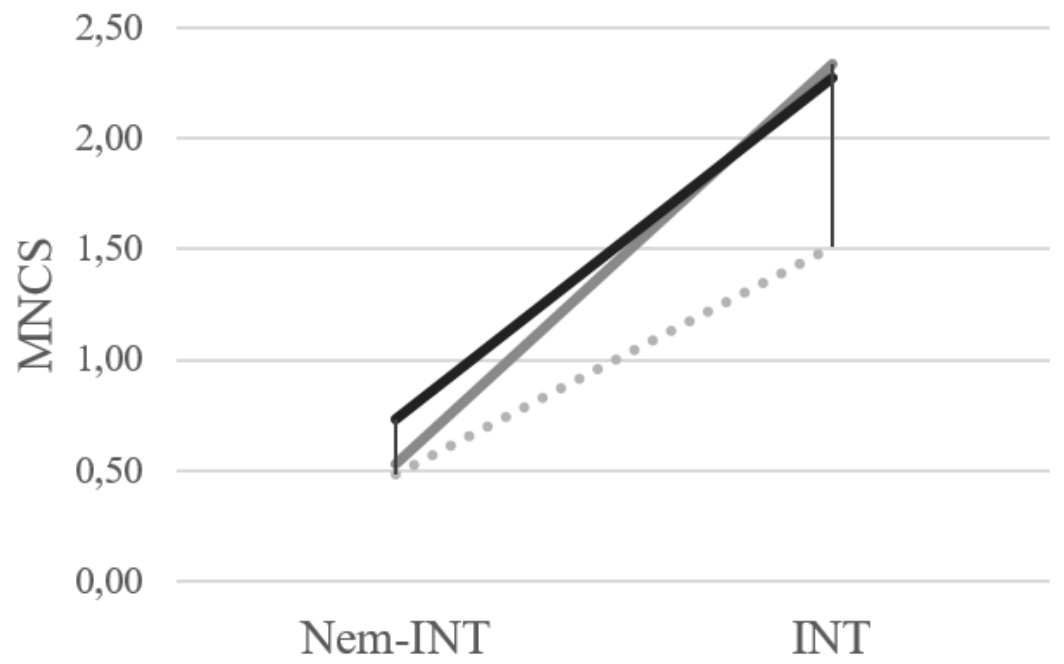

Nemzetközi társszerzőség

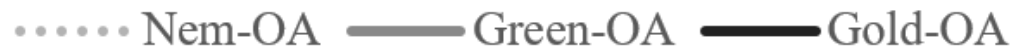

3. ábra: A nemzetköziesség és az OA-státusz interakciója a vizsgált hazai mintában

5. táblázat: A vizsgált hazai kibocsátás átlagos normalizált idézettsége (MNCS) nemzetköziesség és OA-státusz szerint

\begin{tabular}{lrr}
\hline & Nem-INT & INT \\
Nem-OA & 0.48 & 1.51 \\
Green-OA & 0.53 & 2.34 \\
Gold-OA & 0.73 & 2.27 \\
\hline
\end{tabular}

Az OA-státusz önálló hatása az idézettségre - interferenciák

Vizsgálatunk elsődleges kérdése, hogy a hazai kibocsátás vonatkozásában azonosítható-e a nyílt hozzáférésnek tulajdonítható előny az idézettségre nézve, és ha igen, ez milyen mértékű. 
Az utóbbi részkérdés megválaszolásához az előző szakaszban feltárt interakciókon túl ki kell szűrnünk az ún. interferenciákat is az idézettségi hatás magyarázatában, vagyis azt szükséges kimutatnunk, hogy mennyiben magyarázza a megfigyelhető idézettséget az OAstátusz, ha a hatását elkülönítjük a többi változótól, azaz az idézettséget befolyásoló tényezőktől. Ennek elterjedt módszere a regresszióanalízis, a magyarázó változók (itt: idézettségi faktorok, köztük az OA-mutatók) önálló hatásának kimutatása a magyarázott változóra (itt: az normalizált idézettségre).

A hazai mintára vonatkozó regresszióanalízis során a következő modellt építettük fel. A magyarázó változók között a kibocsátás mutatóinak fentiekben leírt három csoportját szerepeltettük: (1)A tudományterületi kategóriákat, (2) Az idézettségi hatás legfontosabb további tényezőit, amely csoport a szerzőszám, a folyóiratrang és a nemzetköziesség mutatóit foglalta magában, illetve (3) a számunkra kérdéses, OAstátuszt leíró változószettet ( $\mathrm{Non} \mathrm{OA}$, GoldOA, only.green). A kezdeti modellt a lehető legjobb illeszkedés biztosítása érdekében teszteltük: az ún. modellszelekciós eljárás egyrészt az összes felsorolt mutató beválasztását igazolta, másrészt, dacára a fent bemutatott interakcióknak, a mutatók interakcióját rögzítő további változók beemelését nem támogatta (az illeszkedés nem javult az eredeti modellhez képest). Az eredmények értelmezéséhez fontos megjegyzés, hogy a célváltozót, a normalizált idézettségi hatás (NCS) mutatóját szokásosan átalakítva, az értékek logaritmusát véve foglaltuk a modellbe, amellyel az erősen ferde eloszlású változóból a lineáris többszörös regresszió követelményeinek megfelelő normál eloszlású változót hoztunk létre („log-normálás”). Mindezek nyomán a végső modellt leíró regressziós egyenlet az alábbi kompakt formát öltötte:

$$
b_{0}+\sum_{n} b_{T(n)} T(n)+\sum_{m} b_{I(m)} I(m)+\sum_{u} b_{O A(u)} O A(u)=\ln N C S
$$


ahol

- $T_{(\mathrm{n})}$ az ESI tudományterületeket kódoló kétértékű változók sorozata $(n=22)$,

- $I_{(\mathrm{m})}$ az idézettségi faktorok sorozata, vagyis a coAU, Int, Q12 változók háromtagú együttese $(m=3)$,

- $\mathrm{OA}_{(\mathrm{u})}$ az OA-státuszt reprezentáló indikátorok, vagyis a NonOA, GoldOA, only.green változók háromtagú csoportja $(u=3)$.

A regressziós eljárás eredményeit a 6. táblázat foglalja össze. A táblázat a fentiek szerint csoportosított magyarázó változók, idézettségi faktorok becsült együtthatóját, vagyis önálló hatásának mértékét ismerteti (azok további sztenderd statisztikai jellemzőivel együtt). A tábla végén a modell érvényességét, illeszkedésének mértékét kifejező paraméterek szerepelnek. Ezek közül kiemelendő az R-négyzet relatíve magas értéke $\left(R^{2}>0.5\right)$, amely érték a társadalomtudományi modellek körében kifejezetten szorosnak tekinthető illeszkedést közvetít, azaz a kapott egyenlet igen jól magyarázza a tényleges idézettségeket.

$\mathrm{Az}$ együtthatókat (b-értékeket) tekintve megállapítható, hogy a nyílt hozzáférés önállóan is növeli a közlemények normalizált idézettségét. Közelebbről, míg a Nem-OA kategória becsült együtthatója negatív előjelű, azaz hozzájárulása a várható idézettséghez negatív, addig mindkét OA-kategória (GoldOA, only.green) pozitív előjellel, illetve hozzájárulással rendelkezik. Ugyanakkor mind a negatív, mind a pozitív hatások mértéke kicsi, különösen, ha összevetjük a többi idézettségi faktor hatásával. A nemzetköziesség és a folyóiratrang (illetve néhány tudományterületi kategória) elkülönített hatása többszöröse az OA-státusz idézettségi szorzójának. Az OA-státuszok közül ismét kiemelkedik azonban a Green út: önálló hatása felülmúlja a Gold út és a nem-OA közlés idézettségre gyakorolt befolyásának mértékét. (A regressziós tábla vonatkozásában célszerű megjegyezni, hogy a szignifikanciaszintek feltüntetése ebben az esetben jórészt formalitás - valódi jelentése vizsgálatunkban az együtthatóknak, vagyis az egyes változókhoz tartozó hatásméretnek van). 
6. táblázat: A regresszió eredményei

\begin{tabular}{lrrrrrr}
\hline Magyarázó változó & $\begin{array}{c}\text { együttható } \\
\text { (b) }\end{array}$ & $\begin{array}{c}\text { standard } \\
\text { együttható } \\
\text { (beta) }\end{array}$ & $\begin{array}{c}\text { Std. } \\
\text { Error }\end{array}$ & $\operatorname{Pr}(>|t|)$ & Sig \\
\hline coAU & 0.00 & 0.16 & 0.00 & 0 & $0 . * * *$
\end{tabular}

Tudományterület

Agricultural

Sciences

0.18

0.03

0.02

8.40694E-18

Biology \&

Biochemistry

0.09

0.03

$0.01 \quad$ 1.63545E-09

Chemistry

0.11

0.05

0.01

4.31037E-16

Clinical Medicine

0.20

0.12

0.01

1.92485E-63

Computer Science

0.10

0.01

0.02

4.56154E-05

Economics \&

Business

0.20

0.03

0.03

6.50208E-15

Engineering

0.18

0.05

0.01

8.96867E-34

Environment/

Ecology

0.23

0.05

0.02

6.8117E-36

Geosciences

0.17

0.03

$0.02 \quad 5.76652 \mathrm{E}-19$

Immunology

0.07

0.01

0.02

0.000665231

Materials Science

0.07

0.01

$0.02 \quad 0.001237296$

Mathematics

0.17

0.05

0.02

9.75336E-29

Microbiology

0.22

0.03

0.02

3.22963E-21

Molecular Biology

\& Genetics

0.13

0.03

0.02

6.58871E-12

Multidisciplinary

0.21

0.01

0.06

$0.00062357^{* * *}$

Neuroscience \&

Behavior

0.15

0.04

0.02

1.75229E-20 


\begin{tabular}{|c|c|c|c|c|c|}
\hline Magyarázó változó & $\begin{array}{l}\text { együttható } \\
\text { (b) }\end{array}$ & $\begin{array}{c}\text { standard } \\
\text { együttható } \\
\text { (beta) }\end{array}$ & $\begin{array}{l}\text { Std. } \\
\text { Error }\end{array}$ & $\operatorname{Pr}(>|t|)$ & Sig \\
\hline $\begin{array}{l}\text { Pharmacology \& } \\
\text { Toxicology }\end{array}$ & 0.13 & 0.03 & 0.02 & 4.68273E-16 & $* * *$ \\
\hline Physics & 0.10 & 0.04 & 0.01 & $2.07035 \mathrm{E}-11$ & $* * *$ \\
\hline $\begin{array}{l}\text { Plant \& Animal } \\
\text { Science }\end{array}$ & 0.22 & 0.07 & 0.01 & 1.62147E-50 & $* * *$ \\
\hline $\begin{array}{l}\text { Psychiatry/ } \\
\text { Psychology }\end{array}$ & 0.19 & 0.04 & 0.02 & 4.11331E-23 & $* * *$ \\
\hline $\begin{array}{l}\text { Social Sciences, } \\
\text { general }\end{array}$ & 0.24 & 0.06 & 0.02 & $1.08324 \mathrm{E}-49$ & $* * *$ \\
\hline Space Science & 0.15 & 0.03 & 0.02 & $2.71863 \mathrm{E}-13$ & $* * *$ \\
\hline \multicolumn{6}{|l|}{$\begin{array}{l}\text { Nemzetköziesség, } \\
\text { presztizs }\end{array}$} \\
\hline HUN.int & 0.23 & 0.22 & 0.01 & 0 & $* * *$ \\
\hline HUN.Q12 & 0.26 & 0.28 & 0.01 & 0 & $* * *$ \\
\hline \multicolumn{6}{|l|}{ OA-státusz } \\
\hline HUN.NonOA & -0.08 & -0.07 & 0.01 & $1.02662 \mathrm{E}-13$ & $* * *$ \\
\hline HUN.GoldOA & 0.08 & 0.05 & 0.01 & $1.37766 \mathrm{E}-12$ & $* * *$ \\
\hline only.green & 0.10 & 0.06 & 0.01 & 9.17531E-18 & $* * *$ \\
\hline \multicolumn{6}{|l|}{ Modell-illeszkedés } \\
\hline R-négyzet & 0.54 & & & & \\
\hline Korrigált R-négyzet & 0.54 & & & & \\
\hline F-próba értéke & 1872.00 & & & & \\
\hline $\mathrm{p}<$ & 0.00 & & & & \\
\hline
\end{tabular}




\section{DisZKuSSZIó ÉS KÖVETKEZTETÉSEK}

A fenti elemzésekkel fó célunk az volt, hogy a hazai kibocsátás egy időben jól körülhatárolt szegmensére nézve megvizsgáljuk a nyílt hozzáférésű publikálás általánosan posztulált idézettségi előnyét. Vizsgálatunk lépcsőzetesen építkezett, ennek során igyekeztünk az OA-alapstatisztikáktól elmozdulva módszeresen elválasztani egymástól az idézettségre befolyással bíró tényezők szerepét, ilyen módon pedig elkülöníteni és felmérni az OA-státusz tényleges, önálló hozzájárulását a közlemények tudományos hatásához.

A vizsgálatok alapján megállapíthatjuk, hogy az OA-típusú publikációs utak hazai viszonylatban (vagyis a hazai kibocsátás tekintetében) is idézettségi előnnyel rendelkeznek a nem-OA típusú úthoz képest. Az alapstatisztikák ezt az előnyt egyértelműen közvetítik, ahol az OA-kategóriák számottevő idézettségi fölényt élveznek. A részletes vizsgálatok szintén megerősítik, hogy az előny létezik. Az OA-státusz és az idézettséget befolyásoló legfontosabb tényezők összefüggésének (interakciójának) elemzése során láthatóvá vált, hogy a nyílt utak a többi változó (folyóiratrang, nemzetköziesség, szakterület) minden - vagy majdnem minden - értéke mellett magasabb átlagos idézettségi hatást váltanak ki. Az OA önálló, a többi tényező hatásától függetlenített szerepét feltáró regresszió pedig egyértelmű pozitív hozzájárulást tulajdonított az OA-kategóriáknak a tudományos hatás mértékére nézve. Külön kiemelendő, fontos eredmény a Green OA „teljesítménye”, amely minden elemzés szerint meghaladja a Gold és a Nem-OA hozzájárulását.

A fenti summázat ugyanakkor az éremnek csak az egyik oldala. Vizsgálatunk céljait tekintve talán ennél is fontosabb eredmény, hogy az alapstatisztikák tudósította képet jelentősen árnyalják a részletes elemzések, mégpedig az idézettségi előny OA-státuszhoz köthető mértékét tekintve. Az OA-hozzájárulás mértéke, amely az alapstatisztikák értelmében számottevő, jóval szerényebbnek adódik, ha az idézettségi előnyt felbontjuk annak tényezői (köztük az OA-státusz) 
szerint. Egyfelől, az interakciók vizsgálata megmutatta, hogy a többi idézettségi faktor - elsősorban a folyóiratrang és a nemzetköziesség - értékeinek változása (pl. a Q1-Q2 kategóriába, vagy a nemzetközi együttműködésben készült közlemények körébe való átlépés) jelentősen módosítja (növeli) az átlagos idézettséget, jóval nagyobb mértékben, mint a nem-OA körben. Ezzel összhangban az OA elkülönített szerepét jellemző regressziós együtthatók értéke is igen csekély, összehasonlítva, megintcsak, a másik két legfontosabb mutatóéval (Q12, INT). Számszerű példát tekintve modellünk alapján: ha egy nemzetközi átlagnak megfelelő idézettségü $(N C S=1)$ nem-OA közleménynek csupán egyetlen paraméterét, az OA-státuszát változtatjuk (elméletben), mégpedig úgy, hogy GoldOA-közlemény legyen, akkor a GoldOA-státusz önálló hatását kifejező becsült együttható $(b=0.08)$ alapján jósolt idézettsége NCS $=1$ helyett NCS = 1.08 lesz. Másként fogalmazva, az OA-státusz 8\%-os növekményt jósol a (normalizált) idézettségben, a világátlaghoz képest ebben a speciális esetben (1-től különböző NCS-értékek esetén ez az összefüggés nem ennyire egyszerű, emlékezzünk rá, hogy az egyenletben az NCS-értékek logaritmusával számolunk).

A fentieket összegezve elmondható, hogy az eredmények óvatos optimizmusra adnak indokot az OA-közlés hazai hozadékát illetően, ami a tudományos hatást illeti. Vizsgálataink alátámasztják, hogy ha a nagyhatású idézettségnövelő tényezőknél kevésbé meredeken is, de a nyílt hozzáférés is hozzáad a várható akadémiai elismeréshez. Ami azonban talán még ennél is lényegesebb, a fenti megközelítés rávilágít annak fontosságára, hogy az OA-előnyök empirikus azonosítása során túllépjünk az alapvető összefüggéseken és egyszerű statisztikai összehasonlításokon (pl. az OA- és a nem-OA közlemények idézettsége között), és igyekezzünk a tudományos kommunikáció és információ ökoszisztémájának teljesebb kontextusában elhelyezni a kérdést, hogy hitelesebb képet kapjunk ennek a kiemelten fontos kérdéskörnek a jellemzőiről. 


\section{IRODALOMJEGYZÉK}

Aman 2014

Aman, V., Is there any measurable benefit in publishing preprints in the arXiv section Quantitative Biology?, arXiv preprint arXiv:

https://arxiv.org/1411.1955, 2014.

Anderson 2013

Anderson, B. R., Funding sources of impactful and transformative research, San Jose State University, 2013.

Atchison \& Bull 2015

Atchison, A., Bull, J., Will open access get me cited? An analysis of the efficacy of open access publishing in political science, PS: Political Science \& Politics, 48(1), 2015, 129-137. https://doi.org/10.3917/polaf.137.0129

Craig et al. 2007

Craig, I. D., Plume, A. M., McVeigh, M. E., Pringle, J., Amin, M., Do open access articles have greater citation impact?: a critical review of the literature, Journal of Informetrics, 1(3), 2007, 239-248.

https://doi.org/10.1016/j.joi.2007.04.001

Davis 2011

Davis, P. M., Open access, readership, citations: a randomized controlled trial of scientific journal publishing, The FASEB journal, 25(7), 2011, 2129-2134. https://doi.org/10.1096/fj.11-183988

Evans \& Reimer 2009

Evans, J. A., Reimer, J., Open access and global participation in science, Science, 323(5917), 2009, 1025. https://doi.org/10.1126/science.1154562

Eysenbach 2006

Eysenbach, G., Citation advantage of open access articles, PLoS biology, 4(5), 2006, e157. https://doi.org/10.1371/journal.pbio.0040157

Gentil-Beccot et al. 2010

Gentil-Beccot, A., Mele, S., Brooks, T., Citing and reading behaviours in high-energy physics, Scientometrics, 84(2), 2010, 345-355.

https://doi.org/10.1007/s11192-009-0111-1 
Hajjem et al. 2006

HajJem, C., Harnad, S., Gingras, Y., Ten-year cross-disciplinary comparison of the growth of open access and how it increases research citation impact, arXiv preprint https://arxiv.org/abs/cs/0606079, 2006.

Kousha \& Abdoli 2010

Kousha, K., Aвdoli, M., The citation impact of Open Access agricultural research: A comparison between $\mathrm{OA}$ and non-OA publications, Online Information Review, 2010.

Langham-Putrow et al. 2021

Langham-Putrow, A., Bakker, C., Riegelman, A., Is the open access citation advantage real? A systematic review of the citation of open access and subscription-based articles, PLOS ONE, 16(6), 2021, e0253129.

https://doi.org/10.1371/journal.pone.0253129

Lawrence 2001

LAWRENCE, S., Free online availability substantially increases a paper's impact, Nature, 411(6837), 2001, 521. https://doi.org/10.1038/35079151

McCabe \& Snyder 2014

McCabe, M. J., Snyder, C. M., Identifying the effect of open access on citations using a panel of science journals, Economic inquiry, 52(4), 2014, 1284-1300. https://doi.org/10.1111/ecin.12064

Sahu et al. 2005

Sahu, D. K., Gogtay, N. J., Bavdekar, S. B., Effect of open access on citation rates for a small biomedical journal, 2005.

Swan 2010

Swan, A., The Open Access citation advantage: Studies and results to date. Technical Report. School of Electronics \& Computer Science, University of Southampton, 2010

Tahamtan et al. 2016

Tahamtan, I., Afshar, A. S., Ahamdzadeh, K., Factors affecting number of citations: a comprehensive review of the literature, Scientometrics, 107(3), 2016, 1195-1225. https://doi.org/10.1007/s11192-016-1889-2 
The Working Group on Rewards under Open Science. Evaluation of research careers and fully acknowledging open science practices, Luxembourg, Publications Office of the European Union, 2017. https://doi.org/10.2777/75255

Wagner 2010

Wagner, A. B. (2010). Open access citation advantage: An annotated bibliography. Issues in science and technology librarianship, 60(2)

Wang et al. 2015

Wang, X., Liu, C., MaO, W., FAng, Z., The open access advantage considering citation, article usage and social media attention, Scientometrics, 103(2), 2015, 555-564. https://doi.org/10.1007/s11192-015-1547-0

Wohlrabe \& Birkmeier 2014

Wohlrabe, K., Birkmeier, D., Do open access articles in economics have a citation advantage?, 2014.

Xu et al. 2011

Xu, L., Liu, J., FAng, Q., Analysis on open access citation advantage: an empirical study based on Oxford open journals = Proceedings of the 2011 iConference, 2011, 426-432. https://doi.org/10.1145/1940761.1940819

\section{Zhang 2006}

ZHANG, Y., The effect of open access on citation impact: a comparison study based on web citation analysis, 2006. https://doi.org/10.1515/LIBR.2006.145

Zhao 2010

Zнао, D., Characteristics and impact of grant-funded research: a case study of the library and information science field, Scientometrics, 84(2), 2010, 293-306. 


\section{Open Science \\ NYÍLT TUDOMÁNY MAGYAR SZEMMEL}


A Magyar Tudományos Akadémia Könyvtárának Közleményei Publicationes Bibliothecae Academiae Scientiarum Hungaricae

$45(120)$
UJ SOROZAT

SOROZATSZERKESZTő

GaÁlné Kalydy Dóra 


\section{Open Science \\ NYÍLT TUDOMÁNY MAGYAR SZEMMEL}

Magyar Tudományos Akadémia

KöNYVTÁr ÉS InFORMÁcIÓs KözPONT

BUDAPEST 2021 


\author{
Szerkesztette \\ GaÁlné Kalydy DóRA \\ Anyanyelvi lektor \\ MóNOK MÁRIA \\ Az irodalomjegyzékeket készítette \\ BudAI-KirÁLY TÍmEA \\ Tipográfia és tördelés \\ VAs ViKTória \\ ISBN 978-963-7451-73-7 \\ ISSN 0133-8862 \\ DOI 10.36820/MTAKIK.KOZL.2021.OpenS
}

Felelős kiadó: az MTA Könyvtár és Információs Központ főigazgatója

Nyomta és kötötte az Alföldi Nyomda Zrt., Debrecen

Felelős vezető: GYöRGy GÉzA vezérigazgató

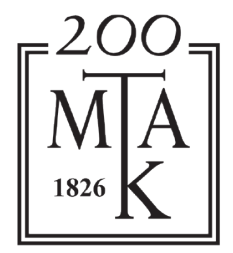

Megjelent a Nemzeti Kulturális Alap támogatásával

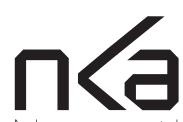

Nemzeti Kulturális Alap 


\section{TARTALOM}

\section{Monok István}

Cui bono, seu cui prodest?

Holl András

A tudományos szakkönyvtárak és a nyílt tudomány

(Open Science)

GaÁlnÉ Kalydy Dóra

A kiadókkal kötött Read and Publish szerződések, és a nyílt hozzáférésű publikálás hazai lehetőségei

Soós SÁndor, Kiss AnNA

Az „Open Access-előnyök" megnyilvánulása

a hazai tudásprodukcióban: bibliometriai hatásvizsgálat

61

\section{GaÁlné Kalydy Dóra}

A közösségi tudomány

\section{Tiberius Ignat}

What motivates us to develop the

Focus on Open Science series?

\section{Hoczopán Szabolcs, Molnár Tamás}

Az egyetemi könyvtárak szerepe a nyílt tudomány

mozgalom elterjesztésében

\section{Holl ANDrás}

Az MTA KIK gyakorlata a nyílt tudomány támogatásában $\quad 161$

A kötetben szereplő tanulmányok szerzői

A Magyar Tudományos Akadémia Könyvtárának

Közleményei, Új Sorozat közelmúltban megjelent kötetei 